\title{
Entrepreneurship Education at Secondary Level in Transition Economies: A Case of Poland
}

\author{
Tomasz Rachwał, Sławomir Kurek, Marta Boguś
}

\begin{abstract}
A B S T R A C T
Objective: The goal of the paper is to present changes in entrepreneurship education (EE) in Poland at lower and upper-secondary schools after the reform of the education system of 1999 in the light of the national core curriculum (NCC) analysis.

Research Design \& Methods: The analysis of the NCC was based on the method and criteria developed in the European research project Fifobi and includes four basic competencies related to the following: economy knowledge, business knowledge, social competences and self-competences associated with entrepreneurial attitudes.
\end{abstract}

Findings: The analysis of content distribution of the NCC for secondary schools indicates that competencies in the field of economic knowledge prevail, the contents of all entries in this field are based on the obligatory subjects "civics" (lower-secondary) "Basics of Entrepreneurship"["BE"] (upper-secondary). Social and self-competencies are treated quite marginally in the NCC.

Implications \& Recommendations: The need to clarify the records of the NCC and modification of the NCC records in terms of entrepreneurship so that a greater emphasis was placed on social and personal competencies, not only the competencies based on economic knowledge.

Contribution \& Value Added: The article can contribute to a better understanding of the level and structure of EE in Poland. The research conclusions may serve as guidelines to educational policy, not only in Poland but also in other countries transforming their economies, and to international comparative studies.

\begin{tabular}{ll}
\hline Article type: & research paper \\
& curriculum development; entrepreneurship education (EE); entre- \\
Keywords: & preneurship curriculum; national core curriculum (NCC) transition \\
& economies; secondary education
\end{tabular}

JEL codes: $\quad$ A21, 121, L26, P36, P46

Received: 15 January $2016 \quad$ Revised: 20 February $2016 \quad$ Accepted: 22 February 2016

\section{Suggested citation:}

Rachwał, T., Kurek, S., \& Boguś, M. (2016). Entrepreneurship Education at Secondary Level in Transition Economies: A Case of Poland. Entrepreneurial Business and Economics Review, 4(1), 61-81, DOI: http://dx.doi.org/10.15678/EBER.2016.040105 


\section{INTRODUCTION}

The main task of entrepreneurship education (EE) is to prepare young people to enter the labour market, as well as to develop a sense of initiative and entrepreneurial skills among them. Therefore, it is important how national education systems adapt to changing skill requirements within a globalised economy, in particular in the post-communist countries which joined the European Union (e.g. Berger et al., 2012; Tracz, 2005; Wach, 2008, 2013, 2014a).

The process of transformation of the national economy in Poland and other Central and Eastern European countries, associated with the transition from the socialist, centrally planned economy to the market economy, occurring under conditions of the processes of globalisation of the world economy and European integration, affects the need for proper preparation of the society to function in an increasingly complex socioeconomic reality. This preparation takes place primarily within the education system, through the development of entrepreneurial attitudes at all stages of development of a young person, from the early school stage to higher education institutions.

The role of school education in shaping entrepreneurial attitudes of a person ready to undertake different kinds of challenges in the market economy is all the more important in Poland and other Central and Eastern European countries. This is a consequence of the situation that often education and professional experience of parents of the youth turns out to be insufficient, given the different conditions of the centrally planned economy in which a significant proportion of parents lived for a long time. In this situation it is difficult to transfer experience related to the functioning in a market economy, especially in running an own business. The development of entrepreneurship is considered a particularly important factor of economic growth in the transition countries. In the time of centrally planned economy and at the beginning of the process of economic transformation, EE was limited to specialised schools and higher education institutions at courses in economics. This kind of education within general education for all students in primary and secondary education was virtually non-existent. A student was not prepared to set up or to run his or her own enterprise, to manage the household budget, to know how to invest available financial resources (e.g. on the stock exchange or in investment funds), to open a bank account, or to obtain credit. Students were not prepared for efficient and effective interpersonal communication, including resolving conflicts or leading negotiations, which are the key competencies deciding of a man's competitiveness nowadays. Thus, students (except for graduates of some business schools), were not prepared well to participate in social and economic life, including being professionally active and establishing own businesses (Rachwał, 2005, 2010; Kurek, Rachwał, 2010a,b, 2011).

\section{LITERATURE REVIEW}

Changes in EE have been researched into by some scholars from Poland. Particularly, noteworthy are works of Daszkiewicz (2013), Nowak (2014), Rachwał (2004, 2005, 2006), Wach $(2008,2013,2014 a)$ and Zioło (2012) that attempt to assess the role and position of entrepreneurship in the education system in Poland, including also the analysis in the 
context of other European countries (Wach, 2014a; Kurek \& Rachwał, 2010a). They highlight a large role of entrepreneurship in education, as well as EE in the socio-economic development, especially economies in transition, such as Poland (see Wach, 2015a). In this regard, Zioło and Rachwal (2012) indicate a deep association between entrepreneurship and geographical research focused on the development processes of spatial systems in different scales (local, regional, national ones). Much of the research is devoted to entrepreneurship at a higher level of education (e.g. Dorocki \& Borowiec-Gabryś, 2014; Gaweł, 2014; Pietrzykowski, 2011; Piróg, 2015; Płaziak \& Rachwał, 2014); especially the impact of EE on entrepreneurial intentions of students and graduates (Jankowska \& Pietrzykowski, 2012; Kilar \& Rachwał, 2014; Wach, 2015b; Zbierowski, 2014), which refers to research undertaken in other countries (e.g. Bae et al. 2014; Byabashaija \& Katono, 2011; Claar et al., 2012; Fayolle \& Gailly, 2015; Koçoğlu \& Hassan, 2013; Kuehn, 2008). The authors also undertake studies on such issues as the position, aims and teaching methods of EE in Poland at the lower levels of education (e.g. Borowiec \& Rachwał, 2011; Brzozowski, 2014; Rachwał, 2004, 2005, 2006, 2009; Solińska, 2014; Tracz \& Rachwal, 2007, 2008; Tracz, 2005, 2006; Wach, 2007). They also stress the importance of the use of modern teaching aids, including multimedia support and ICT tools (Rachwał, Ratajski \& Zając, 2012; Soczówka, 2007, Śrutowska, 2006; Szmulczyńska, 2006). Aims and the content of EE in the NCC in Poland were analysed by Rachwat (2004, 2006). This author made also the critical evaluation of program changes in the field of EE (Rachwat, 2009).The analysis of the role of the curriculum changes for education and of the competences of entrepreneurship teachers was conducted by Tracz and Rachwat $(2007,2008)$. The analysis was supported by the experiment of implementing the EUfunded education project 'Step into Entrepreneurship', whose aim was to design and implement a pilot testing of innovative program for entrepreneurship development in secondary schools in Poland (Rachwał, Ratajski \& Zając, 2012). Żur (2014a) addresses the role of inspiration in EE. Various researchers also undertake the surveys of the opinions of students, their parents and teachers on the state of EE in Poland, including the opinions on introducing "Basics of Entrepreneurship" ("BE") as a new school subject to secondary education (Osuch \& Osuch, 2006; Osuch, 2012; Tracz, 2015; Ziółkowska-Weiss, 2014). To a lesser extent, the researchers undertake a detailed analysis of the content of education based on the curriculum (the NCC or school curricula), which is the subject of this article. Such studies, limited in scope usually to groups of students from one or few secondary schools, take researchers and entrepreneurship teachers, but rather they relate to the expectations of students in relation to the EE curricula (Sowislok, 2012; Świętek, 2012; Ziółkowska-Weiss, 2014).The findings of the surveys conducted by Ziółkowska-Weiss (2014) and Świętek (2012) show that students positively evaluate the introduction of a new subject "BE" to schools and most of them recognize it as a one of the most important school subjects, useful in adult life. Ziółkowska-Weiss (2014) confirms that students feel that in EE curricula and training programmes too much time is devoted to issues related to the functioning of economy and the economic fundamentals of entrepreneurship, and too little to the development of social and personal entrepreneurial skills.

The issue of EE curriculum and good preparation of young people for life in the new economic reality in schools is of particular interest also in other European countries, not 
just those transforming their economies, which also frequently take up the work on reforming education systems in such a way as to encourage the development of business competencies (Canning, Berger \& Pilz, 2012; Berger \& Pilz, 2012; Figueira, 2012; Gönczöl \& Bognár, 2012; Kurek \& Rachwał, 2010; Kurek, Rachwał \& Szubert, 2012a; McGlynn, Canning \& Dolan, 2012; Muzis, Liepins, Roze \& Krastins, 2012; Schwarz, 2012). This is due to the fact that entrepreneurship is one of the pillars of the European education system (Commission..., 2006; Recommendation..., 2006), as so called key competence (Key Competencies, 2002).

\section{MATERIAL AND METHODS}

The goal of the article is to present changes in entrepreneurship education (EE) in Poland at lower secondary (gymnasium) and upper secondary (post-gymnasium) schools after the reform of the education system of 1999 in the light of the national core curriculum (NCC) analysis.

The research on the NCC records is mainly based on the criteria of analysis (described in details later in the article) developed within EU-funded international project Fifobi: Fit for business - developing business competences in school, conducted in the years 2009-2011 (Kurek \& Rachwał, 2010b; Pilz, 2012; Canning, Berger \& Pilz, 2012), especially on the results of the analysis of lower-secondary education made by the Polish team (Kurek, Rachwat \& Szubert, 2012a). These results of the research on the NCC for gymnasium have been extended to general education (applicable to all students) in secondary schools. The findings from the analysis of the NCC is presented against the background of changes in the position of EE in the education system in Poland after the 1999 reform.

This research is also based on previous analyses of the authors, referring to changes in entrepreneurship education in Poland at various levels of education (e.g. Borowiec \& Rachwał, 2011; Kurek \& Rachwał, 2010b, 2011; Kurek, Rachwał \& Szubert, 2012b; Rachwał, 2004, 2005, 2006, 2009, 2010; Tracz \& Rachwał, 2007, 2008; Zioło \& Rachwał, 2012).

\section{RESULTS AND DISCUSSION}

\section{Entrepreneurship Education in Poland at Secondary Level}

In addition to changes of institutional and organisational nature, new goals and teaching contents were introduced in the new education system, according to 1999 reform, within new subjects, such as "Basics of Entrepreneurship" ("BE") whereas the teaching contents of the remaining subjects, such as Civics or Geography were significantly modernised. In this respect, the introduction of a new obligatory subject " $B E$ " for all students in secondary (post-gymnasium) schools, and changes of the goals and teaching contents of the subject Civics in gymnasium, in which elements of entrepreneurship were included, are particularly noteworthy (Rachwał, 2009). The new core curriculum for gymnasium was applied from the school year 2009/2010 in the first years of gymnasium, whereas in the post-gymnasium school from the school year 2012/2013.

In gymnasium, the contents of entrepreneurship education have been included in the subject of Civics, although, as the experience and earlier research (Kurek, Rachwat 
\& Szubert, 2012a) show, these contents are marginalised by teachers of that subject. In post-gymnasium schools ending with secondary school final exams there are planned 60 hours of "BE" and 30 hours of an optional subject of Economy in Practice ("EP"; if a student chooses it), whereas, in vocational schools, 60 hours of "BE" without the possibility to conduct that optional subject.

For the Civics subject which is conducted at the lower-secondary educational level (gymnasium), the following groups of entrepreneurship teaching contents are outlined (numbering in accordance with the core curriculum, the remaining items refer to civic education):

24. Work and entrepreneurship.

25. Market economy.

26. Household.

27. Money and banks.

28. National economy.

29. The enterprise and economic activities.

30. School and profession choices.

31. Ethics in economic life.

Also groups of contents partially connected with entrepreneurship:

20. European integration (including EU budget).

21. Poland in the European Union (including the Union funds).

23. Problems of the contemporary world (including economy globalisation).

Whereas groups of contents for the subject "BE" conducted at the upper-secondary educational level (post-gymnasium school) include the following items:

1. The entrepreneurial person.

2. Market - features and functions.

3. Market institutions.

4. State, economy.

5. The enterprise.

6. Labour market.

Group content within the subject "EP" optionally implemented in secondary schools include the following:

1. Project planning of economic character.

2. Analysis of the market.

3. The organisation of the project.

4. Evaluation of the effects of actions.

The analysis of the detailed records of the core curriculum and the distribution of content groups between the two education levels indicate that the scope of contents for gymnasium is too vast in comparison to post-gymnasium school. It appears that with such a limited number of content hours in gymnasium (ca. 20 hours), the problems of conducting economic activities (item 29) as a serious issue demanding a more mature approach, should be transferred from gymnasium to the secondary school level, or the number of hours allotted for the entrepreneurship contents in gymnasium should be increased (Rachwał, 2009). 
In response to the needs arising from the institutional reform of the education system and the curriculum reform of $E E$, as part of this work a concept of teaching a new subject in secondary school, "BE", was developed. As a result, a number of editions of specialist publications appeared on the market, including textbooks for students and teachers in the field of entrepreneurship and a dictionary of "Basics of Entrepreneurship"; most of them were prepared by the stuff of Pedagogical University of Cracow (PUC). Moreover, a draft of the core curriculum of "BE" in the extended version was prepared by the team of PUC and Cracow University of Economics.

Serious shortcomings in the new system of EE are the lack of possibility to implement it on the upper-secondary level in the extended content (with more than the standard number of hours) and taking the maturity exam in this subject, although the accepted model of secondary school in Poland allows students to select a subject from a wide choice (except compulsory courses as Polish language, mathematics and a foreign language). This optional extension of the content of entrepreneurship education would allow to take final upper secondary school exams in "BE" both at the basic and the extended level. This issue drew the attention of many authors (e.g. Barton, 2005; Rachwat, 2006, 2009, Tracz \& Rachwat, 2008). However, the issue of matriculation exam in entrepreneurship still remains unresolved. It should be noted that their implementation is delayed due to the controversial nature of many technical and organisational difficulties associated with it, in which the opponents of the introduction of exams in this course include:

- a contradiction with the essence of entrepreneurship, which deals more with skills and attitudes rather than knowledge-based economic competencies,

- difficulties in defining the criteria for checking skills,

- a danger of departing from skills training to equipping students with economic knowledge and thus transforming the course into "principles of economics",

- incomparability of the range of requirements with other subjects (too narrow content),

- reducing the attractiveness of the subject for students and their involvement in the classroom, because teachers need to implement the material just for final exams.

It is, however, important to cite arguments of the proponents of the introduction of this exam (Bartoń, 2005), i.e.:

- expanding the catalogue of matriculation subject to choose from for students,

- the possibility of obtaining the certificate of maturity in an economic subject,

- greater opportunity to evaluate the candidates for business schools,

- greater prestige of entrepreneurship in the structure of the school teaching,

- greater involvement of students in the classroom (because of the awareness that the subject is covered by an external test),

- increasing the role of economic education for the society and the popularisation of entrepreneurial attitudes in society.

Therefore, the opinion of Barton (2005) must be accepted that - following the experiences of other countries, including many European countries - the subject of " $\mathrm{BE}$ " as the only economic subject in general education should be considered as a matriculation subject. In addition, the possibility of carrying out matriculation examination in this sub- 
ject in Poland is shown by a successful project 'The Entrepreneurship Contest', which de facto has become such an "external examination", however, giving the possibility of entering economic studies only to the winners), as well as contests and competitions on entrepreneurship organised in many schools and educational institutions in Poland.

Furthermore, the development of information and computer technologies has a major impact on the implementation of the curriculum by teachers from virtually all subjects, especially in "BE" and "EP". As noted by Soczówka (2007), since the introduction of computers into schools in Poland in the 1980s, these devices and their software have become one of the important means of teaching used in such entrepreneurship education. Nowadays, computer programmes and multimedia have become an indispensable part of the learning process. If we want to teach effectively and the learning process to become easy and enjoyable, we should use the form that best reaches the students. Thanks to that, we could arouse their interest in teaching material. Multimedia teach through playing, which supports the teaching-learning process. They expand the cognitive area, facilitate consolidation of the material and help to check the degree of mastery of knowledge. And, most importantly, they are interactive, so the teacher activates the students and motivates them to work (Śrutowska, 2006).

This is confirmed by the opinions of the students themselves, cited on the basis of the research conducted under the auspices of the National Bank of Poland (Narodowy Bank Polski), by Smulczyńska (2006): according to students the increased use of teaching aids, the use of different, attractive and engaging ways of working, enhancing the practical aspect of teaching of the subject and strengthening contacts with institutions and enterprises would increase their satisfaction with participation in basic entrepreneurship lessons. These studies have also shown that teachers and school headmasters appreciate the role of activating methods, including the use of modern technology in educational work, but they often do not apply them because of limited time and technical capabilities. This was confirmed in studies by other authors, but good progress in this regard in Polish schools should be noted as a result of increasing universal access to computers and high-tech audio-visual and electronic teaching tools (Rachwał, Ratajski \& Zając, 2012).

\section{Curriculum Analysis in Gymnasium (Lower Secondary School) and General Education in Post-Gymnasium (Upper-Secondary) Schools}

In order to determine the content of entrepreneurship education in Poland a detailed analysis of the records of the NCC was carried out. The analysis was based on the criteria developed in the European research project Fifobi (Pilz, 2012) and includes four basic competencies related to the following: economy knowledge (E), business knowledge (B), social competences (SO) and self-competences associated with an entrepreneurial attitude (SE). Detailed criteria include the content shown in the table below (Table 1).

The analysis of Poland's new NCC of general education was based on the regulation of the Ministry of National Education announced on 12 December 2008 (Rozporządzenie... 2009) and implemented in the $2009 / 2010$ school year. Apart from civic education, other relevant courses during which content connected with business education at lower-secondary level is realised include: mathematics and Polish (Kurek, Rachwał \& Szubert, 2012). 
Table 1. Coding for the curriculum analysis

A. Sub-competencies/criteria in the field of knowledge-based competencies in economics

\begin{tabular}{|c|c|c|}
\hline $\begin{array}{l}\text { Criteria of knowledge-based competencies } \\
\text { in economics }\end{array}$ & Code & Possible text in the curriculum \\
\hline $\begin{array}{l}\text { Basic principles of economics } \\
\text { Further explanations: Understanding economics as } \\
\text { the study of how society manages its scarce re- } \\
\text { sources; understanding of basic economic phenom- } \\
\text { ena }\end{array}$ & E1 & $\begin{array}{l}{[\ldots] \text { recognize that an economic }} \\
\text { order is necessary for the form of } \\
\text { social life }\end{array}$ \\
\hline $\begin{array}{l}\text { The market forces of supply and demand } \\
\text { Further explanations: Elasticity and its application } \\
\text { (how much buyers and sellers respond to changes } \\
\text { in market conditions); aggregate demand and } \\
\text { aggregate supply (the aggregate-demand curve and } \\
\text { the aggregate-supply curve) }\end{array}$ & E2 & $\begin{array}{l}\text { [...] understand the functionality of } \\
\text { market and be able to reflect the } \\
\text { roles of participants in market } \\
\text { events }\end{array}$ \\
\hline $\begin{array}{l}\text { Trade and globalisation } \\
\text { Further explanations: International trade (the } \\
\text { effects of international trade on economic well- } \\
\text { being); open-economy macroeconomics and mac- } \\
\text { roeconomic theory of the open economy }\end{array}$ & E3 & $\begin{array}{l}\text { [...] know the world-economic inter- } \\
\text { relationship and be aware of the } \\
\text { consequence of globalisation }\end{array}$ \\
\hline $\begin{array}{l}\text { Actors in the market } \\
\text { Further explanations: Consumers, producers and } \\
\text { the efficiency of markets; understanding how } \\
\text { different actors in the market behave; understand- } \\
\text { ing of the theory of consumer choice }\end{array}$ & E4 & $\begin{array}{l}{[\ldots] \text { show consumer-conscious be- }} \\
\text { haviour in purchase situation and be } \\
\text { able to justify the purchase-decision }\end{array}$ \\
\hline $\begin{array}{l}\text { The monetary system } \\
\text { Further explanations: Saving, investment and the } \\
\text { financial system; money growth and inflation; } \\
\text { understanding of the role of money in economy }\end{array}$ & E5 & $\begin{array}{l}\text { [...] know the danger and methods } \\
\text { of debt and excessive indebtedness, } \\
\text { know provision of help for debt } \\
\text { relief and reflect on one's own } \\
\text { consumer behaviour }\end{array}$ \\
\hline $\begin{array}{l}\text { Government policies and its influences } \\
\text { Further explanations: The design and costs of the } \\
\text { tax system; externality (for instance, economy and } \\
\text { ecology); public goods and common resources } \\
\text { (goods without market prices); monetary and fiscal } \\
\text { policy }\end{array}$ & E6 & $\begin{array}{l}{[\ldots] \text { know the tasks and aims of state }} \\
\text { environment policies }\end{array}$ \\
\hline $\begin{array}{l}\text { Market forms } \\
\text { Further explanations: Firms in competitive market; } \\
\text { monopoly; oligopoly }\end{array}$ & E7 & $\begin{array}{l}{[\ldots] \text { know different market forms }} \\
\text { and their influence on the pricing }\end{array}$ \\
\hline $\begin{array}{l}\text { Firms on the market } \\
\text { Further explanations: Costs of production; The } \\
\text { behaviour of competitive firms; factors of produc- } \\
\text { tion (for instance, labour, land, and capital) }\end{array}$ & E8 & $\begin{array}{l}\text { [...] describe the tasks of companies } \\
\text { in economic processes }\end{array}$ \\
\hline $\begin{array}{l}\text { Income } \\
\text { Further explanations: Earnings and discrimination; } \\
\text { income inequality and poverty }\end{array}$ & E9 & $\begin{array}{l}\text { [...] differentiate earned income and } \\
\text { investment income }\end{array}$ \\
\hline $\begin{array}{l}\text { Indicators of economy } \\
\text { Further explanations: GDP, CPI... }\end{array}$ & E10 & \\
\hline $\begin{array}{l}\text { Labour market } \\
\text { Further explanations: Unemployment; short-run } \\
\text { trade-off between inflation and unemployment }\end{array}$ & E11 & $\begin{array}{l}\text { [...] recognize structure-conditioned } \\
\text { unemployment problem }\end{array}$ \\
\hline
\end{tabular}


B. Sub-competencies/criteria in the field of knowledge-based competencies in business

\begin{tabular}{|c|c|c|}
\hline $\begin{array}{l}\text { Criteria of knowledge-based competencies } \\
\text { in business }\end{array}$ & Code & Possible text in the curriculum \\
\hline $\begin{array}{l}\text { Business and its external environment } \\
\text { Further explanations: Various types of business } \\
\text { activity and organisation; financial institutions and } \\
\text { their role in the financial structure; business external } \\
\text { environment, e.g. economic systems, structure of } \\
\text { industry, location of industry }\end{array}$ & B1 & $\begin{array}{l}{[\ldots] \text { recognize that an economic }} \\
\text { order is necessary for the form of } \\
\text { social life }\end{array}$ \\
\hline $\begin{array}{l}\text { Corporate strategy and planning } \\
\text { Further explanations: Methods used in forecasting } \\
\text { and planning enterprise goals and department objec- } \\
\text { tives; the nature of decisions and methods of statisti- } \\
\text { cal analysis in making decisions }\end{array}$ & B2 & $\begin{array}{l}\text { [...] understand the functionality of } \\
\text { market and be able to reflect the } \\
\text { roles of participants in market } \\
\text { events }\end{array}$ \\
\hline $\begin{array}{l}\text { Organising } \\
\text { Further explanations: Organisation structure, levels } \\
\text { of organisation; importance of authority, responsibil- } \\
\text { ity, and delegation }\end{array}$ & B3 & $\begin{array}{l}{[\ldots] \text { know the world-economic }} \\
\text { interrelationship and be aware of } \\
\text { the consequence of globalisation }\end{array}$ \\
\hline $\begin{array}{l}\text { Directing } \\
\text { Further explanations: Leadership, relationship and } \\
\text { communication between managers and employees }\end{array}$ & B4 & $\begin{array}{l}{[\ldots] \text { show consumer-conscious }} \\
\text { behaviour in purchase situation } \\
\text { and be able to justify the purchase- } \\
\text { decision }\end{array}$ \\
\hline $\begin{array}{l}\text { Controlling } \\
\text { Further explanations: Principles of effective control, } \\
\text { budgetary and non-budgetary, financial accounting } \\
\text { conventions }\end{array}$ & B5 & $\begin{array}{l}\text { [...] know the danger and methods } \\
\text { of debt and excessive indebted- } \\
\text { ness, know provision of help for } \\
\text { debt relief and reflect on one's } \\
\text { own consumer behaviour }\end{array}$ \\
\hline $\begin{array}{l}\text { Marketing and sales management } \\
\text { Further explanations: Selling, transportation, stor- } \\
\text { age, gathering market information, etc. }\end{array}$ & B6 & $\begin{array}{l}{[\ldots] \text { know the tasks and aims of }} \\
\text { state environment policies }\end{array}$ \\
\hline $\begin{array}{l}\text { Production and operation management } \\
\text { Further explanations: Production function; the place } \\
\text { of product design and development; the location of } \\
\text { plant; the layout of equipment; the importance of } \\
\text { planning and control }\end{array}$ & B7 & $\begin{array}{l}{[\ldots] \text { know different market forms }} \\
\text { and their influence on the pricing }\end{array}$ \\
\hline $\begin{array}{l}\text { Human resource management } \\
\text { Further explanations: Recruitment selection; training } \\
\text { and development; promotion and transfer; redun- } \\
\text { dancy and retirement, }\end{array}$ & B8 & $\begin{array}{l}\text { [...] describe the tasks of companies } \\
\text { in economic processes }\end{array}$ \\
\hline $\begin{array}{l}\text { Administrative management } \\
\text { Further explanations: Planning and organising the } \\
\text { office; office machinery and equipment; human } \\
\text { aspects of computer usage }\end{array}$ & B9 & $\begin{array}{l}\text { [...] differentiate earned income } \\
\text { and investment income }\end{array}$ \\
\hline $\begin{array}{l}\text { Business ethics } \\
\text { Further explanation: ethical behaviour of a contrac- } \\
\text { tor, employer and employee, black economy, mech- } \\
\text { anism of corruption }\end{array}$ & $\begin{array}{l}\mathrm{B} 10 \\
(\mathrm{PL})\end{array}$ & $\begin{array}{l}\text { [...] clarify the mechanism of cor- } \\
\text { ruption and explains/presents the } \\
\text { effects of this phenomenon for the } \\
\text { economy }\end{array}$ \\
\hline
\end{tabular}


C. Sub-competencies/criteria in the field of knowledge-based competencies in business

\begin{tabular}{|c|c|c|}
\hline Criteria of social competencies & Code & Possible text in the curriculum \\
\hline $\begin{array}{l}\text { Communication ability } \\
\text { Further explanations: A person has the ability to } \\
\text { communicate, when he/she is able to express } \\
\text { him/herself verbally and nonverbally and interpret } \\
\text { other people's messages properly and know how to } \\
\text { react based on them }\end{array}$ & SO1 & $\begin{array}{l}{[\ldots] \text { must strive to understand com- }} \\
\text { municatively [...] can illustrate clearly } \\
\text { their point of view with examples }\end{array}$ \\
\hline $\begin{array}{l}\text { Conflict ability } \\
\text { Further explanations: Conflict ability is concerned } \\
\text { with recognizing a clash of interests and the will- } \\
\text { ingness to resolve them amicably }\end{array}$ & $\mathrm{SO} 2$ & $\begin{array}{l}{[\ldots] \text { have the possibility to set about }} \\
\text { conflicts fairly and peacefully }\end{array}$ \\
\hline $\begin{array}{l}\text { Ability to give and receive criticism } \\
\text { Further explanations: Ability to give and receive } \\
\text { criticism. Someone who is ready and able to deal } \\
\text { with other people's mistakes constructively and } \\
\text { fairly }\end{array}$ & SO3 & $\begin{array}{l}\text { [...] accept different ideas [...] be able } \\
\text { to understand criticism of one's own } \\
\text { behaviour not as a personal attack, } \\
\text { but rather as criticism on the subject } \\
{[\ldots] \text { know how to cope with conflicts }} \\
\text { constructively }\end{array}$ \\
\hline $\begin{array}{l}\text { Team ability } \\
\text { Further explanations: Readiness and competence } \\
\text { to cooperate with other members of a group in a } \\
\text { goal and task-oriented way }\end{array}$ & SO4 & [...] always work in a team \\
\hline $\begin{array}{l}\text { Empathy } \\
\text { Further explanations: Understand the situation of } \\
\text { other people and to deal with them politely, and } \\
\text { with respect }\end{array}$ & SO5 & [...] deal with others with respect \\
\hline
\end{tabular}

D. Sub-competencies/criteria in the field of self- competencies with emphasis on entrepreneurial thinking

\begin{tabular}{|l|l|l|}
\hline \multicolumn{1}{|c|}{$\begin{array}{c}\text { Criteria of self-competencies } \\
\text { with the emphasis on entrepreneurial thinking }\end{array}$} & Code & Possible text in the curriculum \\
\hline $\begin{array}{l}\text { Internal locus of control } \\
\text { Further explanations: It refers to the extent to } \\
\text { which individuals believe that they can largely con- } \\
\text { trol their actions and the consequences of their } \\
\text { actions. Individuals with a high internal locus of } \\
\text { control believe that events result primarily from } \\
\text { their own behaviour and actions. (Decision-making } \\
\text { ability; assertiveness; self-marketing; organising } \\
\text { competence; visionary thinking) }\end{array}$ & SE1 & $\begin{array}{l}\text { [...] is able to make a decision, to set } \\
\text { own priorities [...] organise the pro- } \\
\text { cess of work; }\end{array}$ \\
\hline $\begin{array}{l}\text { Achievement motivation } \\
\text { Further explanations: People who are strongly } \\
\text { achievement-motivated set goals for themselves } \\
\text { and look for affirmation of their accomplishments; } \\
\text { (Plan, organise, readiness for intellectual achieve- } \\
\text { ment; orientation towards achievement; motivation } \\
\text { for achievements; goal-orientation; lifelong learn- } \\
\text { ing; resistance against stress, ability to work under } \\
\text { pressure) }\end{array}$ & SE2 & $\begin{array}{l}{[\ldots] \text { know that crisis is a part of life and }} \\
\text { know the possibilities to overcome } \\
\text { them [...] is willing to spark his/her } \\
\text { competencies as entrepreneur }\end{array}$ \\
\hline
\end{tabular}




\begin{tabular}{|l|c|l|}
\hline \multicolumn{1}{|c|}{$\begin{array}{c}\text { Criteria of self-competencies } \\
\text { with the emphasis on entrepreneurial thinking }\end{array}$} & Code & Possible text in the curriculum \\
\hline $\begin{array}{l}\text { Eagerness for independence } \\
\text { Further explanations: It is understood as the quest } \\
\text { for autonomy and self-fulfilment. People with out- } \\
\text { standing eagerness for independence orientate their } \\
\text { actions and decisions on their own plans and evalua- } \\
\text { tion, seldom or not at all on authority. (Personal } \\
\text { independence; leadership; creativity; imagination) }\end{array}$ & SE3 & $\begin{array}{l}{[\ldots] \text { develop learning goal and }} \\
\text { theme independently }\end{array}$ \\
\hline $\begin{array}{l}\text { Moderate tendency to take risks } \\
\text { Further explanations: People with this characteristic } \\
\text { are ready to take risks, without being careless. } \\
\text { (Readiness for moderate risks; entrepreneurial } \\
\text { thinking as employee; grasp for trends and market } \\
\text { developments) }\end{array}$ & SE4 & $\begin{array}{l}\text { [...] learn to perceive and evaluate } \\
\text { one's strengths and weaknesses }\end{array}$ \\
\hline $\begin{array}{l}\text { Entrepreneurial attitude } \\
\text { Further explanation: Features of entrepreneurial } \\
\text { person, taking entrepreneurial action }\end{array}$ & $\begin{array}{l}\text { SE5 } \\
\text { (PL) }\end{array}$ & $\begin{array}{l}{[\ldots] \text { present features and abilities }} \\
\text { of an entrepreneurial person }\end{array}$ \\
\hline
\end{tabular}

Sources: own compilation based on (Berger et al. 2012; Pilz, Berger, Canning, ed., 2012) based on Appleby (1994), Bader (2007), Mankiw (2001).

Within other subjects a few hours can be devoted to the realisation of contents associated with developing entrepreneurship competencies. However, it is not officially defined how many hours should be devoted to the realisation of the content in business education within these subjects. The decision is left up to teachers.

The analysis of the NCC indicates that schools should equip students of gymnasium relatively well with economic knowledge. Taking into account four groups of competences in the NCC, the economic knowledge content prevails (Figure 1).

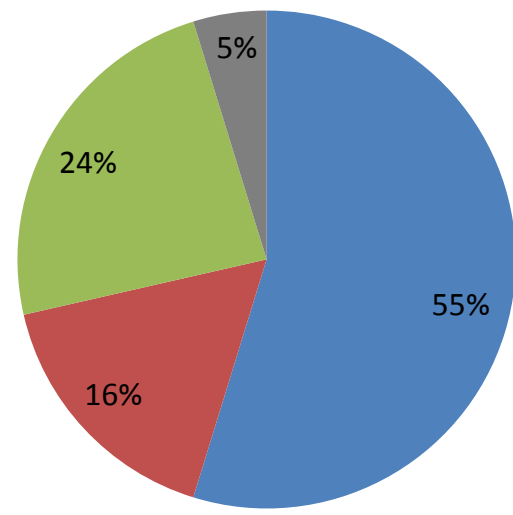

Knowledge based competencies in economics

Knowledge based competencies in business

Social competencies

- Self competencies with emphasis on entrepreneurial thinking

Figure 1. The percentage distribution of the main groups of records of the NCC in lower secondary school (gymnasium) concerning entrepreneurship competencies Source: own compilation.

Nevertheless, significant deficiencies refer to market forms (E7). A detailed diagram shows that records in competencies associated with economic knowledge are mostly 
represented (i.e. E11, E5, E6, E9, E10 and E1), as well as SO1 competencies (Figure 2). Business competencies in a narrow sense, i.e. directly associated with conducting business activity, are also introduced by the NCC. They are only limited to sections within civic education. A difference between the needs and the NCC has been detected in a few fields which are either barely taught or missing completely (Figure 3). This refers to the content associated with the structure of corporate strategy and planning (B2), which deals with directing people (including leadership), and relationships and communication between managers and employees (B4). These issues are limited to ethic values in business. Those connected with the principles of controlling and accounting (B5), production and operation management (B7) and administration (B9) are non-existent. Besides the limited content, the NCC includes an additional criterion of "black economy" and corruption (B10 PL), so omnipotent in modern economy.

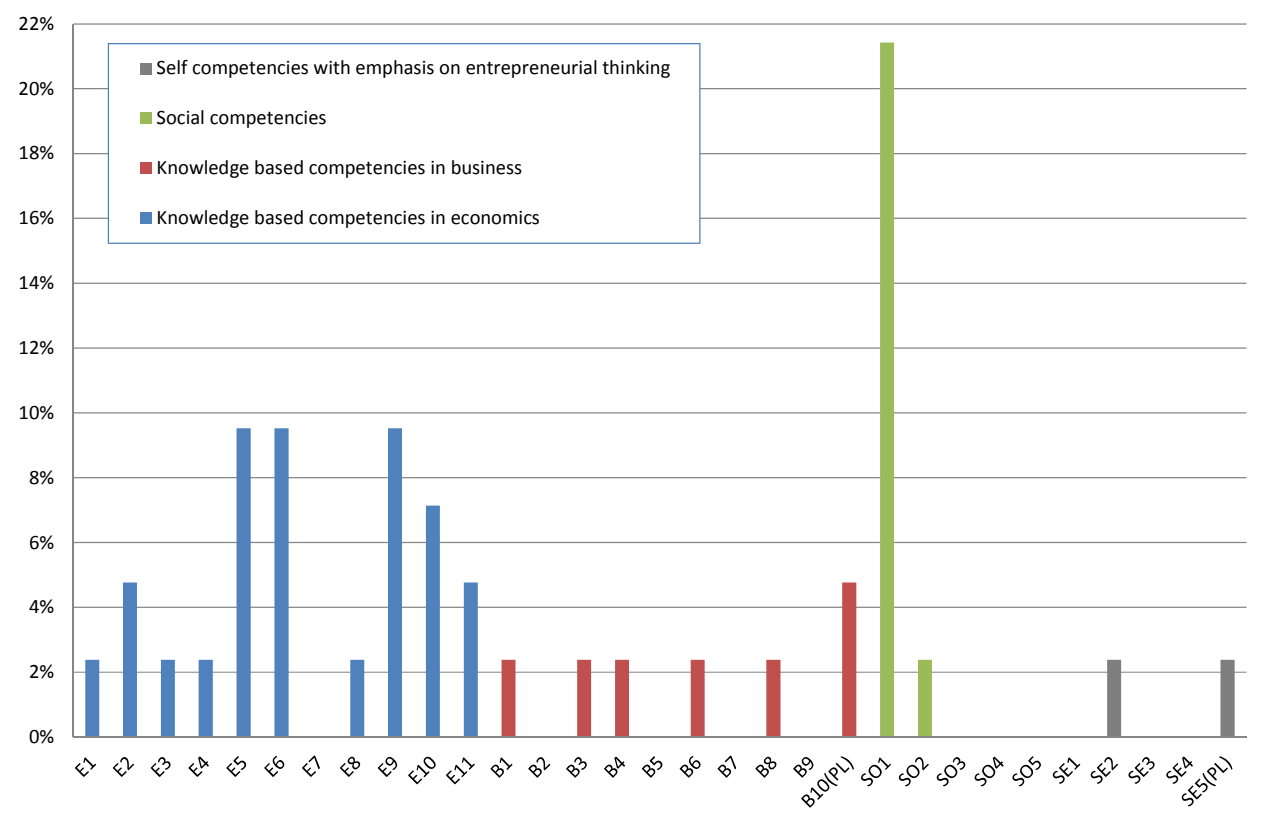

Figure 2. The percentage distribution of records of the NCC in lower secondary school (gymnasium) concerning entrepreneurship competencies

Source: own compilation.

According to the NCC, social competencies should be mainly developed during lessons of Polish and social education (called "family life education"). Surprisingly, no regulations regarding this competence are found in civic education. The curriculum stresses communication skills (SO1) and conflict management skills (SO2). In the latter case, the content is covered during the social education classes. There, conflict resolution concerns children-parents relations, but it may be assumed that students will acquire competencies of solving conflicts in their future place of employment. Furthermore, the curriculum lacks teaching content associated with the skills of giving and taking criticism (SO3) and empathy (SO5). Another missing skill is teamwork (SO4). Such a skill is crucial due to increasing specialisation, as well as the need for group solving of complicated 
problems found in every work environment. The importance of teamwork skills has rich literature devoted to it, mainly concerning team management. However, according to S. Covey $(1989,2004)$, creative, synergetic cooperation in a team is one of the eight basic elements of effectiveness of every person, not only an effective manager-leader.

The analysis of the NCC concerning self-competencies associated with entrepreneurial thinking shows they almost do not occur in the teaching content. The curriculum for lower secondary school (gymnasium) does not anticipate developing the skill of selfcontrol (SE1, SE3, SE4). The only area which might refer to the development of the entrepreneurial attitude is that of making plans for further education. However, the learning outcomes at the lower secondary level contain the following phrase "[student will be able to] present features and skills of an entrepreneurial person; participate in public undertakings which enable development", which was marked as a typical Polish element - SE5 PL.

The analysis of the distribution of content of the NCC in upper secondary schools indicates that competencies in the field of entrepreneurship are implemented directly on the two subjects dedicated to entrepreneurship education, that is "BE" obligatory for all students and "EP", optional, chosen by the students,. It should be noted, however, that this optional subject cannot be chosen by the students of basic vocational schools, and it is only for general and technical upper secondary schools. This is due to the fact that vocational students have various additional subjects or prepare to run a business in their vocational education. Generally, competencies in the field of economic knowledge prevail, constituting $57 \%$ of the total (Figure 3 ), the contents of all entries in this field are based on the obligatory subject "BE". The second group consists of knowledge-based competencies in business, but most of the entries appear in the optional subject "EP", and therefore cannot be implemented for all students. Self-competencies are treated quite marginally in the NCC.

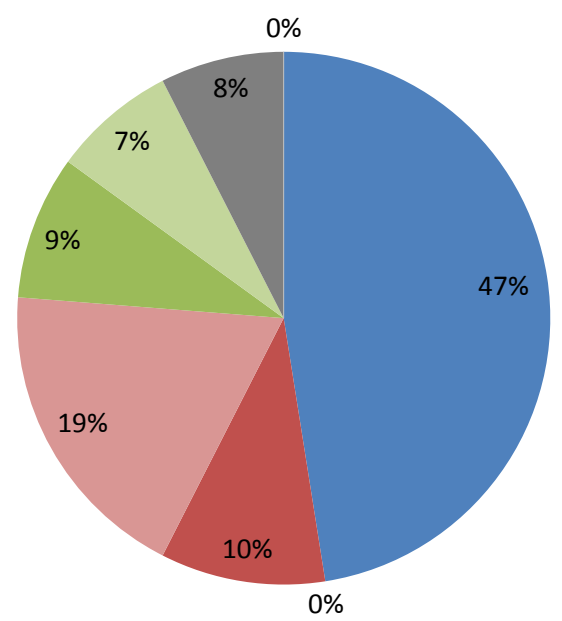

Knowledge based competencies in economics
(OBLIGATORY)
Knowledge based competencies in economics
(OPTIONAL)
Knowledge based competencies in business
(OBLIGATORY)
Knowledge based competencies in business
(OPTIONAL)
Social competencies (OBLIGATORY)
Social competencies (OPTIONAL)
Self competencies with emphasis on
entrepreneurial thinking (OBLIGATORY)
Self competencies with emphasis on
entrepreneurial thinking (OPTIONAL)

Figure 3. The percentage distribution of the main groups of records of the NCC Curriculum in upper secondary (post-gymnasium) school concerning entrepreneurship competencies Source: own compilation. 
The detailed analysis of the content of the NCC indicates that the best represented content in the records of the curriculum are the issues of the monetary system (E5), government policies and its influences (E6) and the labour market (E11) - Figure 4. A large share of the content is also represented by the business and its external environment (B1), but mainly in the optional subject "EP". A relatively high proportion of social skills related to interpersonal communication, conflict resolution and team work (SO1, SO2, SO4) also refers to this subject. It should be noted that too much important content is carried out under an optional, not obligatory course, which should not be assessed as the best solution.

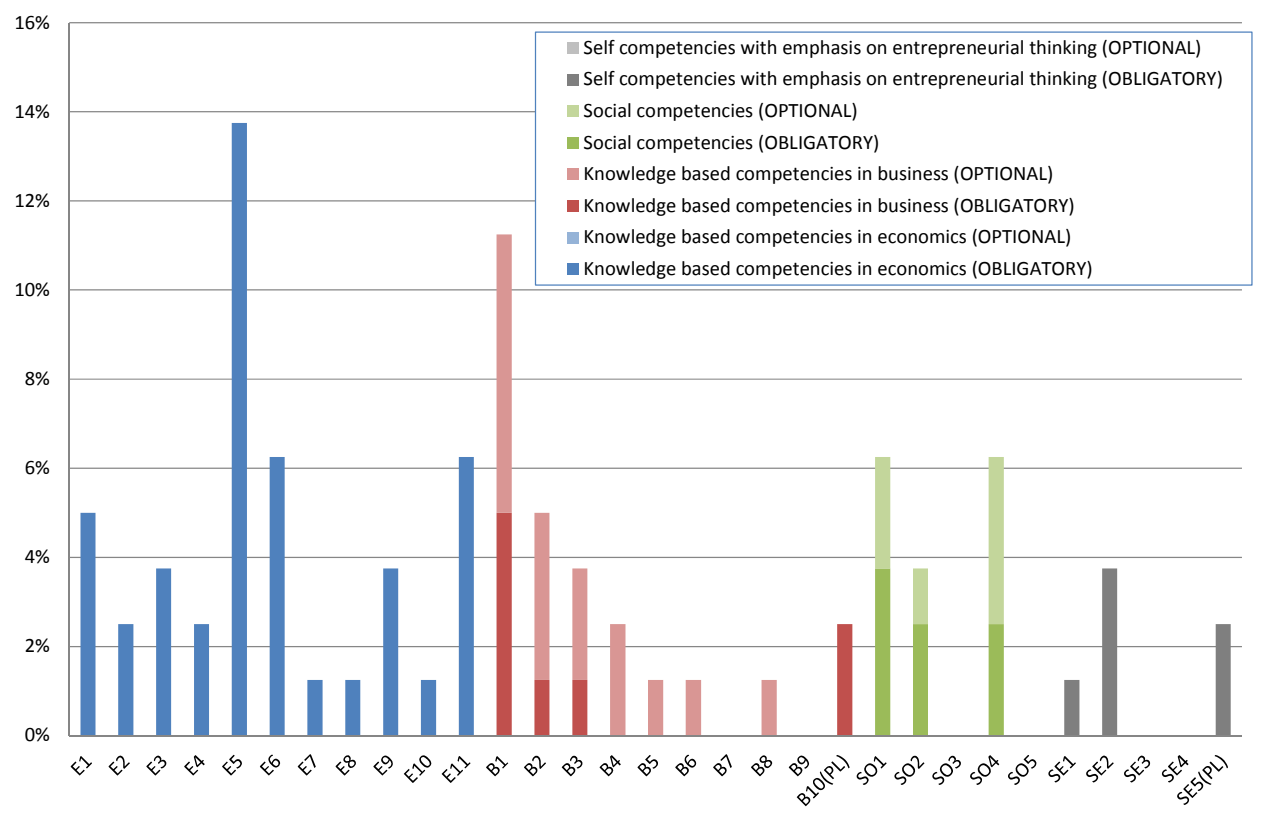

Figure 4. The percentage distribution of records of the NCC in a upper secondary (post-gymnasium) school concerning entrepreneurship competencies Source: own compilation.

The conclusions from the analysis of the national core curriculum in gymnasium were confronted with the results of in-depth interviews with social partners (employers' organisations and trade unions) on entrepreneurship education in Polish schools. They emphasised a generally unfavourable opinion about the attitude of the Polish school to equipping with the knowledge economy along with the marginalisation of business knowledge, as well as social and personal skills, important in any profession and therefore so highly requested by employers in the labour market. A detailed analysis of the social partners' opinion is included in the earlier study (Kurek, Rachwał \& Szubert 2012a). These opinions are generally consistent with the views of secondary school students in this field (Ziółkowska-Weiss, 2014).

The findings of the previous comparative research on curriculum in lower-secondary schools of Poland, Scotland and two regions of Germany (Berger et al. 2012) indicated that entrepreneurial competencies were quite different for each of the coun- 
tries/regions, reflecting a range of diverse cultural and socio-economic factors. In the case of North Lanarkshire in Scotland, the emphasis within curriculum was focused upon employability and a transferable skills set within occupational structures. In the two German regions, there was much more emphasis on the wider economic and market environment and collective competencies. While, in the Polish curriculum, the priority subjects within the curriculum were related to wider market economy, including aspects of the labour market and industrial relations. Comparing to Scotland and Germany, very few self or collective social competencies appear within the curriculum in Poland. In fact, a surprising outcome was the apparent absence of business studies within the lowersecondary school curriculum in all three countries (Berger et al. 2012). Furthermore, Canning, Berger and Pilz (2012) show that the knowledge based competencies in economics also dominate in curricula in Austria, Latvia and especially in Hungary, which also transforms its economy. It should be noted, however, that the prevalence of content related to economic knowledge is much greater in Poland than in those other countries.

\section{CONCLUSIONS}

The analysis of content distribution of the NCC for secondary schools indicates that competencies in the field of economic knowledge prevail, the contents of all entries in this field are based on the obligatory subjects "civics" (lower-secondary schools) and "BE" (upper-secondary schools). Social and self-competencies are treated quite marginally in the NCC. Shortcomings in the business competencies, carried out mainly on the compulsory subject "EP", are also visible.

The conducted research allowed to draw a number of conclusions and recommendations or challenges for politicians and educators in entrepreneurship education in Poland. In the light of the analysis, the need for further changes in the education system in Poland can be indicated, so that it supports the formation of more entrepreneurial attitudes. This is reflected in the further reform of the curricula. These should include in particular:

- the need to clarify the records in the NCC, since in many cases the entries are too vague, which means that the teacher cannot be exactly sure which effects are to be achieved,

- the need to modification of the records in the NCC in terms of entrepreneurship so that a greater emphasis was placed on social and personal competencies,

- in the case of upper secondary schools, the content of business knowledge in the obligatory part of education should be strengthened, because students who do not choose an optional subject "EP" will be poorly equipped to operate their own business and therefore it is worth considering whether the subject should be obligatory,

- introducing the possibility to carry out the subject in the extended version and enable to take matriculation exams in entrepreneurship.

The presented analysis can contribute to a better understanding of the level and structure of entrepreneurship education in Poland. An important added value of the analyses is their application value. The conclusions of the research may serve as guidelines to educational policy, not only in Poland but also in other countries transforming their economies, and to international comparative studies. Encouraging an entrepre- 
neurial mind-set and making young people financially literate by engaging them in learning entrepreneurship within the motivating context will help them to enter the workforce or become entrepreneurs. Therefore, raising the level of EE should be reflected in the processes of economic development, especially in the form of small and medium enterprises. It is increasingly important in times of economic crisis as creativity applied through entrepreneurship education can lead to improvements in the transition process from leaving school to entering the labour market.

\section{REFERENCES}

Appleby, R.C. (1994). Modern business administration. 6th ed. London: Pitman.

Bader, R. (2007). Unternehmerische Selbstständigkeitals Thema in Schulbüchern der Berufsschule. Ergebnisseeiner Analyseausgewählter Schulbücher. In R. Bader, G. Keiser, T. Unger, (Eds.), Entwicklungunternehmerischer Kompetenz in der Berufsbildung. Hintergründe, Ziele und Prozesseberufspädagogischen Handelns, Reihe Berufsbildung, Arbeit und Innovation Forschung. Band 31. Bielefeld: Bertelsmann Verlag, 212-227

Bae, T.J., Qian, S., Miao, Ch., \& Fiet, J.O. (2014). The Relationship Between Entrepreneurship Education and Entrepreneurial Intentions: A Meta-Analytic Review. Entrepreneurship Theory and Practice, 38(2), 217-254.

Bartoń, M. (2005). Przedsiębiorczość jako przedmiot matury 2008. Przedsiębiorczość-Edukacja, 1, 255-258.

Berger, S., Canning, R., Dolan, M., Kurek, S., Pilz, M., \& Rachwał, T. (2012). Curriculum-making in pre-vocational education in the lower secondary school: A regional comparative analysis within Europe, Journal of Curriculum Studies, 44(5). DOI: 10.1080/00220272.2012.702223

Berger, S., \& Pilz, M. (2012). The Role of Pre-Vocational Education in the German Realschule: Theory and Practice. In M. Pilz, S. Berger, R. Canning (Eds.), Fit for Business. Pre-Vocational Education in European Schools. Wiesbaden: Springer, 119-144. DOI: 10.1007/978-3-531-19028-0_6

Borowiec, M., \& Rachwał, T. (2011). Kształtowanie postaw przedsiębiorczych na lekcjach geografii wyzwaniem edukacyjnym w procesach globalizacji. Przedsiębiorczość-Edukacja, 7, 321-332.

Brzozowski, T. (2013). Status przedsiębiorczości w warunkach kryzysu edukacji. Przedsiębiorczość Edukacja, 9, 258-272.

Byabashaija, W., \& Katono, I. (2011). The Impact of College Entrepreneurial Education on Entrepreneurial Attitudes and Intention to Start a Business in Uganda, Journal of Developmental Entrepreneurship, 16(1), 127-144.

Canning, R., Berger, S., \& Pilz, M. (2012). A Comparison of Different Pre-Vocational Curricula in Seven European Countries: Theoretical Perspectives and Policy Implications. In M. Pilz, S. Berger, R. Canning (Eds.), Fit for Business. Pre-Vocational Education in European Schools. Wiesbaden: Springer, 191-206. DOI: 10.1007/978-3-531-19028-0_9

Claar, V.V., Frey, R., Szarucki, M., \& TenHaken, V.R. (2012). Hope for the East: entrepreneurial attitudes of MBA students in two transition economies relative to those in the USA. International Journal of Business Excellence, 5(3), 220-237.

Commission Communication on Implementing the Community Lisbon Programme: Fostering entrepreneurial mindsets through education and learning, Brussels, 13.02.2006, COM (2006) 33.

Covey, S.R. (1989). The 7 Habits of Highly Effective People. London: Simon \& Schuster.

Covey, S.R. (2004). The 8 Habit. From Effectiveness to Greatness. London: Simon \& Schuster. 
Daszkiewicz, N. (2013), Education as a Stimulating Factor for Entrepreneurship Development. Horyzonty Wychowania, 13(26), 165-177.

Dorocki, S., \& Borowiec-Gabryś, M. (2014). Problematyka przedsiębiorczości w programie studiów realizowanych w Uniwersytecie Pedagogicznym w Krakowie. Horyzonty Wychowania, 13(28), 65-80.

Fayolle, A., \& Gailly, B. (2015), The Impact of Entrepreneurship Education on Entrepreneurial Attitudes and Intention: Hysteresis and Persistence. Journal of Small Business Management, 53, 75-93. DOI: 10.1111/jsbm.12065

Figueira, E. (2012). The Entrepreneurship Subject in the Portuguese Education System. In M. Pilz, S. Berger, R. Canning (Eds.), Fit for Business. Pre-Vocational Education in European Schools. Wiesbaden: Springer, 177-190. DOI: 10.1007/978-3-531-19028-0_8

Gaweł, A. (2014). Gry strategiczne w edukacji przedsiębiorczej, Horyzonty Wychowania, 13 (26), 303-325

Gönczöl, E., \& Bognár, T. (2012). Economic Knowledge and Entrepreneurial Competencies in PreVocational Education in Hungary. In M. Pilz, S. Berger, R. Canning (Eds.), Fit for Business. PreVocational Education in European Schools. Wiesbaden: Springer, 89-118. DOI: 10.1007/978-3531-19028-0_5

Jankowska, B., \& Pietrzykowski, M. (2012). Postawy proprzedsiębiorcze studentów a profil kształcenia - Polska na tle innych krajów. Przegląd Organizacji, 8, 28-32

Key Competencies. A developing concept in general compulsory education (2002). Eurydice, Brussels.

Kilar, W., Rachwał, T. (2014). Postrzeganie zakładania własnej działalności gospodarczej jako przejaw postawy przedsiębiorczej przez studentów kierunków nieekonomicznych, Horyzonty Wychowania, 13(28), 111-130.

Koçoğlu, M., Hassan, M.U. (2013). Assessing Entrepreneurial Intentions of University Students: A Comparative Study of Two Different Cultures: Turkey and Pakistani, European Journal of Business and Management, 5(13), 243-252.

Kuehn, K.W. (2008). Entrepreneurial Intensions Research: Implications for Entrepreneurship Education. Journal of Entrepreneurship Education, 11, 87-98.

Kurek, S., \& Rachwat, T. (2010a). The Role of Business Education in the Development of Entrepreneurship in the Member States of the European Union. Europa XXI, 19, 127-142.

Kurek, S., \& Rachwał, T. (2010b). Założenia i wstępne wyniki europejskiego projektu badawczego "FIFOBI" w zakresie kształtowania kompetencji uczniów gimnazjum do prowadzenia działalności gospodarczej. Przedsiębiorczość - Edukacja, 6, 472-485.

Kurek, S., \& Rachwał, T. (2011). Development of entrepreneurship in ageing populations of The European Union. Procedia - Social and Behavioral Sciences, 19, 397-405.

Kurek, S., Rachwał, T., \& Szubert, M. (2012a). Business Competencies in Polish School Curricula: Opinions of Teachers and Social Partners. In M. Pilz., S. Berger, R. Canning (eds.), Fit for Business. Pre-Vocational Education in European Schools (pp. 61-88). Wiesbaden: Springer. DOI: 10.1007/978-3-531-19028-0_4

Kurek, S., Rachwał, T., \& Szubert, M. (2012b). Kształtowanie kompetencji biznesowych uczniów gimnazjum $w$ świetle opinii nauczycieli na podstawie wyników badań prowadzonych w ramach europejskiego projektu FIFOBI. Przedsiębiorczość-Edukacja, 8, 24-36.

Mankiw, N.G. (2001). Principles of economics. 2. ed. Fort Worth, Tex.: Harcourt College Publ. 
McGlynn, K., Canning, R., \& Dolan, M. (2012). Pre-Vocational Education in Scotland: A case Study of One Local Authority. In M. Pilz, S. Berger, R. Canning (Eds.), Fit for Business. Pre-Vocational Education in European Schools. Wiesbaden: Springer, 17-34. DOI: 10.1007/978-3-531-19028-0_2

Muzis, I., Liepins, E., Roze, J., \& Krastins, V. (2012). The Development of Business Competencies in School: Latvia's Experience. In M. Pilz, S. Berger, R. Canning (Eds.), Fit for Business. PreVocational Education in European Schools. Wiesbaden: Springer, 35-60. DOI: 10.1007/978-3531-19028-0_3

Nowak, J. (2014). Dyskusja nad rolą edukacji w rozwoju przedsiębiorczości (rozdział 2). W: M. Kokocińska \& H. Nowak (red.), Edukacja w zakresie przedsiębiorczości: doświadczenia Polski i Hiszpanii. Warszawa: Difin.

Osuch, E., \& Osuch, W. (2006). Przedmiot podstawy przedsiębiorczości w opinii uczniów i rodziców na przykładzie wybranych krakowskich szkół. Przedsiębiorczość - Edukacja, 1, 195-202.

Osuch, W. (2012). Podstawy przedsiębiorczości w opinii uczniów krakowskich liceów - szanse i oczekiwania. Przedsiębiorczość - Edukacja, 8, 37-47.

Pietrzykowski, M. (2011). Entrepreneurship in Higher Education - the case of Poland (pp. 113-128). In M. Dabić \& M. Pietrzykowski (Eds.), Fostering Education in Entrepreneurship. Poznań: Wydawnictwo Naukowe Bogucki.

Pilz, M. (2012). Introduction: Questions, Challenges and Methods. In M. Pilz, S. Berger, \& R. Canning (Eds.), Fit for Business. Pre-Vocational Education in European Schools. Wiesbaden: Springer, 7-16. DOI: 10.1007/978-3-531-19028-0_1

Pilz, M., Berger, S., \& Canning, R. (Eds). (2012). Fit for Business. Pre-Vocational Education in European Schools. Wiesbaden: Springer. DOI: 10.1007/978-3-531-19028-0

Piróg, D. (2015). Kompetencje z zakresu przedsiębiorczości: rozważania teoretyczne i ich ilustracje w obszarze szkolnictwa wyższego. Przedsiębiorczość - Edukacja, 11, 364-376.

Płaziak, M., \& Rachwał, T. (2014). Entrepreneurship Courses in Spatial Management Studies in Polish Universities. Procedia - Social and Behavioral Sciences, 110, 710-718, DOI: 10.1016/ j.sbspro.2013.12.915

Rachwał, T. (2004). Cele i treści kształcenia przedsiębiorczości w szkołach ponadgimnazjalnych. In J. Brdulak, M. Kulikowski (Eds.), Przedsiębiorczość stymulatorem rozwoju gospodarczego, Warszawa: Instytut Wiedzy, 263-270.

Rachwał, T. (2005). Kształtowanie postaw uczniów na lekcjach przedsiębiorczości. Przedsiębiorczość-Edukacja, 1, 137-144.

Rachwał, T. (2006). Kształtowanie postaw przedsiębiorczych w edukacji szkolnej. In B. Muchacka (ed.), Szkoła w nauce i praktyce edukacyjnej, t. II. Kraków: Oficyna Wydawnicza „Impuls”, Akademia Pedagogiczna w Krakowie, 427-434.

Rachwał, T. (2009). Ocena projektu zmian podstawy programowej podstaw przedsiębiorczości (przedstawionej przez MEN w 2008 r. w ramach reformy systemu edukacji), PrzedsiębiorczośćEdukacja, 5, 349-372.

Rachwał, T. (2010). Entrepreneurship Education as a Growth Stimulus for Family Firms (chapter 9). In A. Surdej, K. Wach (Eds), Exploring the Dynamics of Entrepreneurship. Torun: Marszałek Publishing House, 139-156.

Rachwał, T., Ratajski P., \& Zając M. (2012). Innowacyjna Strategia Kształcenia „Krok w Przedsiębiorczość". Warszawa: Nowa Era.

Recommendation of the European Parliament and of the Council of 18 December 2006 on key competencies for lifelong learning (2006/962/EC). Official Journal of the European Union, L 394, 30.12.2006. 
Rozporzqdzenie Ministra Edukacji Narodowej z dnia 23 grudnia 2008 r. w sprawie podstawy programowej Wychowania przedszkolnego oraz kształcenia ogólnego w poszczególnych typach szkół. (2009).Dz. U. z dn.15 stycznia 2009 r. Nr 4, poz. 17

Schwarz, I. (2012). Perspectives for Pupils and Teachers in Economic Education: European and Austrian Aspects of the Fifobi Project. In M. Pilz, S. Berger, R. Canning (Eds.), Fit for Business. Pre-Vocational Education in European Schools. Wiesbaden: Springer, 145-176. DOI: 10.1007/978-3-531-19028-0_7

Soczówka, M. (2007). Wykorzystanie technologii informacyjnej w nauczaniu-uczeniu się podstaw przedsiębiorczości. Przedsiębiorczość-Edukacja, 3, 317-324.

Solińska, U. (2014). Kształtowanie postawy przedsiębiorczości wśród uczniów szkół ponadgimnazjalnych jako przygotowanie do aktywności na rynku pracy, Horyzonty Wychowania, 13(28), 303-316.

Sowislok, K. (2012). Przedsiębiorczość w szkole ponadgimnazjalnej na przykładzie II Liceum Ogólnokształcącego w Zabrzu. Przedsiębiorczość - Edukacja, 8, 57-63.

Śrutowska, D. (2006). Wykorzystanie multimediów w nauczaniu przedsiębiorczości (na przykładzie multimedialnego CD-ROM-u Wydawnictwa Nowa Era pt. „Podstawy przedsiębiorczości”. Przedsiębiorczość-Edukacja, 2, 264-278.

Świętek, A. (2012). Oczekiwania a realia wejścia ludzi młodych na rynek pracy jako wyzwanie dla edukacji z przedsiębiorczości. Przedsiębiorczość - Edukacja, 8, 137-154.

Szmulczyńska, B. (2006). Zapotrzebowanie środowiska szkolnego w zakresie edukacji ekonomicznej a oferta edukacyjna Portalu Edukacji Ekonomicznej Narodowego Banku Polskiego NBPortal.pl. Przedsiębiorczość-Edukacja, 2, 279-286.

Tracz, M. (2005). O niektórych kryteriach doboru treści nauczania do podstawy programowej programu nauczania z podstaw przedsiębiorczości. Przedsiębiorczość - Edukacja, 1, 207-212.

Tracz, M. (2006). Rola i znaczenie podstaw przedsiębiorczości w kształceniu ogólnym. Przedsiębiorczość - Edukacja, 2, 222-22.

Tracz, M. (2015). Przedmiot podstawy przedsiębiorczości w opinii uczniów i nauczycieli - stadium porównawcze. Przedsiębiorczość - Edukacja, 11, 391-400

Tracz, M., \& Rachwał, T. (2007). Przedmiot podstawy przedsiębiorczości - założenia realizacji a przygotowanie nauczycieli. Przedsiębiorczość-Edukacja, 3, 286-296.

Tracz, M., \& Rachwał, T. (2008). Metody nauczania i środki dydaktyczne stosowane przez nauczycieli podstaw przedsiębiorczości - wyniki badań. Przedsiębiorczość-Edukacja, 4, 325-330.

Wach, K. (2007). Kształtowanie postaw przedsiębiorczych w programach nauczania: Stan obecny i proponowane kierunki zmian. W: P. Wachowiak, M. Dąbrowski, B. Majewski (ed.), Kształtowanie postaw przedsiębiorczych a edukacja ekonomiczna. Warszawa: Fundacja Promocji Akredytacji Kierunków Ekonomicznych, 120-127.

Wach, K. (2008). Entrepreneurship Education in Poland. ERENET Profile, III(3), 36-44.

Wach, K. (2013). Edukacja na rzecz przedsiębiorczości wobec współczesnych wyzwań cywilizacyjnogospodarczych. Przedsiębiorczość - Edukacja, 2013, 9, 246-257.

Wach, K. (2014a). Edukacja dla przedsiębiorczości: pomiędzy przedsiębiorczą pedagogiką a edukacją ekonomiczną i biznesową. Horyzonty Wychowania, 13(28), 11-31.

Wach, K. (2014b). Europeanisation of Entrepreneurship Education in Europe - Looking Back and Looking Forward. Horyzonty Wychowania, 13(26), 11-32.

Wach, K. (2015a). Przedsiębiorczość jako czynnik rozwoju społeczno-gospodarczego: przegląd literatury. Przedsiębiorczość - Edukacja, 11, 24-36. 
Wach, K. (2015b). Środowisko biznesu rodzinnego jako stymulanta intencji przedsiębiorczych młodzieży akademickiej. Przedsiębiorczość i Zarzqdzanie, XVI(7[III]), 25-40.

Zbierowski, P. (2014). Determinanty intencji przedsiębiorczej studentów - wyniki badań. Horyzonty Wychowania, 13(26), 51-63.

Ziółkowska-Weiss, K. (2014). Problematyka podstaw przedsiębiorczości w opinii uczniów szkoły ponadgimnazjalnej. Przydatność w życiu czy konieczność nauki? Przedsiębiorczość - Edukacja, 10, 366-377.

Zioło, Z. (2012). Miejsce przedsiębiorczości w edukacji. Przedsiębiorczość - Edukacja, 8, 10-23.

Zioło, Z., \& Rachwał, T. (2012). Entrepreneurship in geographical research. In P. Churski (Ed.), Contemporary Issues in Polish Geography. Poznań: Bogucki Wydawnictwo Naukowe, 135-155.

Żur, A. (2014). Exploring the Role of Inspiration in Entrepreneurship Education. Horyzonty Wychowania, 13(26), 179-194. 


\section{Authors}

The contribution share of authors is amounted to $50 \%$ of Tomasz Rachwał, $30 \%$ of Sławomir Kurek and $20 \%$ of Marta Boguś.

\section{Tomasz Rachwał}

PhD, head of the Department of Entrepreneurship and Spatial Management of Institute of Geography of the Pedagogical University of Cracow, a Scientific Secretary of the Industrial Geography Committee of the Polish Geographical Society, A managing editor of the Entrepreneurship -Education journal and a member of the editorial boards of other journals. The author or co-author of school and academic textbooks on economic geography and entrepreneurship. His research interests focus primarily on the issue of change of spatial structures of industry, the functioning of various branches of industrial activity, corporate restructuring and the role of entrepreneurship in the development of spatial systems as well as entrepreneurship education. Correspondence to: Dr Tomasz Rachwał, Pedagogical University of Cracow, Department of Entrepreneurship and Spatial Management, ul. Podchorążych 2, 30-084 Kraków, Poland, e-mail: T.Rachwal@up.krakow.pl

\section{Sławomir Kurek}

$\mathrm{PhD}$, associate professor at the Pedagogical University of Cracow, Institute of Geography, Department of Socio-Economic Geography. A socio-economic geographer. Member of the Committee on Demographic Studies of the Polish Academy of Sciences. He is, among other activities, the Deputy Head for Research and International Relations of Institute of Geography, Head of Doctoral Studies in geography at the Pedagogical University, and Editor in Chief of Annales Universitatis Paedagogicae Cracoviensis, Studia Geographica. Research interests focus primarily on the issue of changes of the socio-demographic structures in Poland and Europe, suburbanisation processes in metropolitan areas, as well as entrepreneurship education.

Correspondence to: Dr hab. Sławomir Kurek, Pedagogical University of Cracow, Department of Entrepreneurship and Spatial Management, ul. Podchorążych 2, 30-084 Kraków, Poland, e-mail: sgkurek@up.krakow.pl

\section{Marta Boguś}

PhD student at the Faculty of Geography and Biology of Pedagogical University of Cracow, Poland. Master in economic geography (Pedagogical University of Cracow, Poland). Her research interests focus on the issues of socio-economic transformation in Poland, the operation of multinational corporations, as well as entrepreneurship education.

Correspondence to: Mgr Marta Boguś, Pedagogical University of Cracow, Department of Entrepreneurship and Spatial Management, ul. Podchorążych 2, 30-084 Kraków, Poland, e-mail: mbogus@up.krakow.pl

\section{Copyright and License}

This article is published under the terms of the Creative Commons Attribution - NonCommercial - NoDerivs (CC BY-NC-ND 3.0) License http://creativecommons.org/licenses/by-nc-nd/3.0/

\footnotetext{
Published by the Centre for Strategic and International Entrepreneurship - Krakow, Poland
} 